\title{
49. DATA REPORT: PRELIMINARY REPORT ON THE OSTRACODES OF LEG 122 (EXMOUTH PLATEAU, INDIAN OCEAN) ${ }^{1}$
}

\author{
Claude Guernet ${ }^{2}$ and Bruno Galbrun ${ }^{2}$
}

\begin{abstract}
The Cenozoic sediments from Holes 762B, 762C, 763A, and 763B yielded about 30 ostracode species. Deep-sea psychrospheric species are present throughout the section. Among the common elements, Actinocythereis orientalis, Bradleya sp. gr. johnsoni, Bradleya ossa, Henryhowella? reticulata and Poseidonamicus sp. 1 are probably the most typical and are all of long stratigraphic range.
\end{abstract}

\section{INTRODUCTION}

Two of the sites drilled during Leg 122 penetrated Paleocene and/or Eocene sediments and have provided an opportunity to study the evolution of Cenozoic bathyal ostracodes. Sites 762 (Holes 762B and 762C) and 763 (Holes 763A and 763B) are located on the western part of the central Exmouth Plateau, in the Indian Ocean, both at a water depth of about $1360 \mathrm{~m}$. The Exmouth Plateau is separated from the Northwest Shelf of Australia by the Carnarvon Basin and is bounded to the north, west, and south by abyssal plains (Haq, von Rad, O'Connell, et al., 1990). Therefore, the Exmouth Plateau, and particularly its northwestern part, is today and was much of the Cenozoic, sheltered from shelf sediment supply and neritic ostracodes.

\section{STRATIGRAPHICAL DISTRIBUTION OF OSTRACODES}

One-hundred twenty-two samples of $5 \mathrm{~cm}^{3}$ each, 97 of which are from Site 762, have been studied. Among these samples, about 20 were devoid of ostracodes, the majority providing one through nine valves. About 30 species were identified; these are noted in Tables 1 and 2. Ostracodes are unusual in the Paleocene, relatively common from the Eocene to middle Miocene, and again unusual from upper Miocene to Quaternary. Interpretation of such fluctuations are tenuous because of the small number of samples. The fluctuations may be related to variations in the sedimentation rate linked to variations in surface productivity.

In other respects, specific diversity is wide enough: 14 species for 45 valves in Sample 122-762C-13X-1, 67-69 cm, and 12 species for 50 valves in Sample 122-762B-17H-1, 20-22 cm. This testifies as to the variety of the ecological niche occupied by ostracodes in a bathyal environment. Beyond the Cytherella, Bairdioidea, and Krithe, of which an accurate identification is generally difficult, the most frequent species in the Cenozoic samples of Sites 762 and 763 are Actinocythereis orientalis orientalis Guernet (1985) (PI. 1, Figs. 1-2), A. orientalis n.s. sp. (PI. 1, Figs. 3 and 6), Bradleya sp. gr. johnsoni Benson, in Benson and Peypouquet (1983) (PI. 1, Fig. 4), B. ossa Whatley, in Whatley et al. (1984) (Pl. 1, Fig. 6), B. cf. thomasi Steineck and Yozzo (1988) (PI. 1, Fig. 5), Henryhowella? reticulata (Guernet, 1985) (PI. 1, Fig. 9), and Poseidonamicus? sp. 1 (Pl. 1, Fig. 7).

\footnotetext{
1 von Rad, U., Haq, B. U., et al., 1992. Proc. ODP, Sci. Results, 122. College Station, TX (Ocean Drilling Program).

Département de Géologie Sédimentaire et U.A. CNRS 1315, Université Curie, 75252 Paris Cedex 05, France.
}

The stratigraphical and geographical range of many of these species is very wide. A. orientalis orientalis, originally described in the Eocene of Ninetyeast Ridge (Site 214) and probably present in the South Atlantic Oligocene (cf. Trachyleberis sp., pl. 2, fig. 8, in Benson and Peypouquet, 1983), extends from the Paleocene to Miocene on the Exmouth Plateau. The same is true for $H$. ? reticulata. A. orientalis $\mathrm{n.s}$. $\mathrm{sp}$. is present from the middle Eocene to Quaternary. Bradleya ossa, known in the southwest Pacific from the Miocene to Quaternary, appears as early as the middle Eocene at Site 762. Some genera or species have more restricted apparent ranges. Bradleya thomasi, reported from the upper Miocene to Holocene in the Pacific, the Mozambique Channel, and the North Atlantic by Steineck and Yozzo (1988), seems to have the same range at the Exmouth Plateau. Nevertheless, if we take into account the small number of ostracodes in each sample, the non-appearance of one species is not necessarily significant and its effective stratigraphical range may be wider than indicated on the charts.

\section{SUMMARY AND CONCLUSIONS}

The Tertiary of Sites 762 (Holes 762B and 762C) and 763 (Holes 763A and 763B) yielded about 30 species of ostracodes, chiefly from the middle Eocene to lower Miocene. The species have large vertical ranges and the bathyal and psychrospheric association Cytherella- "Bairdia"'-Actinocythereis-BradleyaPoseidonamicus is constant from the Eocene to Quaternary. It seems that there is a permanence of bathyal physical conditions throughout the Cenozoic on the Exmouth Plateau.

\section{REFERENCES}

Benson, R. H., and Peypouquet J.-P., 1983. The upper and midbathyal cenozoic ostracode faunas of the Rio Grande Rise found on Leg 72 of the Deep Sea Drilling Project. In Barker, P. F., Carlson, R. L., Johnson, D. A., et al., Init. Repts. DSDP, 72: Washington (U.S. Govt. Printing Office), 808-818.

Guernet, C., 1985. Ostracodes paléogènes de quelques sites "D.S.D.P." de l'Océan Indien (legs 22 et 23). Rev. Paléobiol., 4:279-295.

Haq, B. U., von Rad, U., O'Connell, S., et al., Proc. ODP, Init. Repts., 122: College Station, TX (Ocean Drilling Program).

Steineck, P. L., and Yozzo, D., 1988. The late Eocene-Recent Bradleya johnsoni Benson lineage (Crustacea, Ostracoda) in the Central Equatorial Pacific. J. Micropaleontol., 7:187-189.

Whatley, R., Downing, S., Kesler, K., and Harlow, C. J., 1984. New species of the Ostracod Genus Bradleya from the Tertiary and Quaternary of D.S.D.P. sites in the Southwest Pacific. Rev. Esp. Micropaleontol., 16:265-298.

Date of initial receipt: 12 June 1990

Date of acceptance: 10 December 1990

Ms 122B-171 
Table 1. Range chart for Cenozoic ostracodes from Site 762 (Holes 762B and $762 \mathrm{C})$.

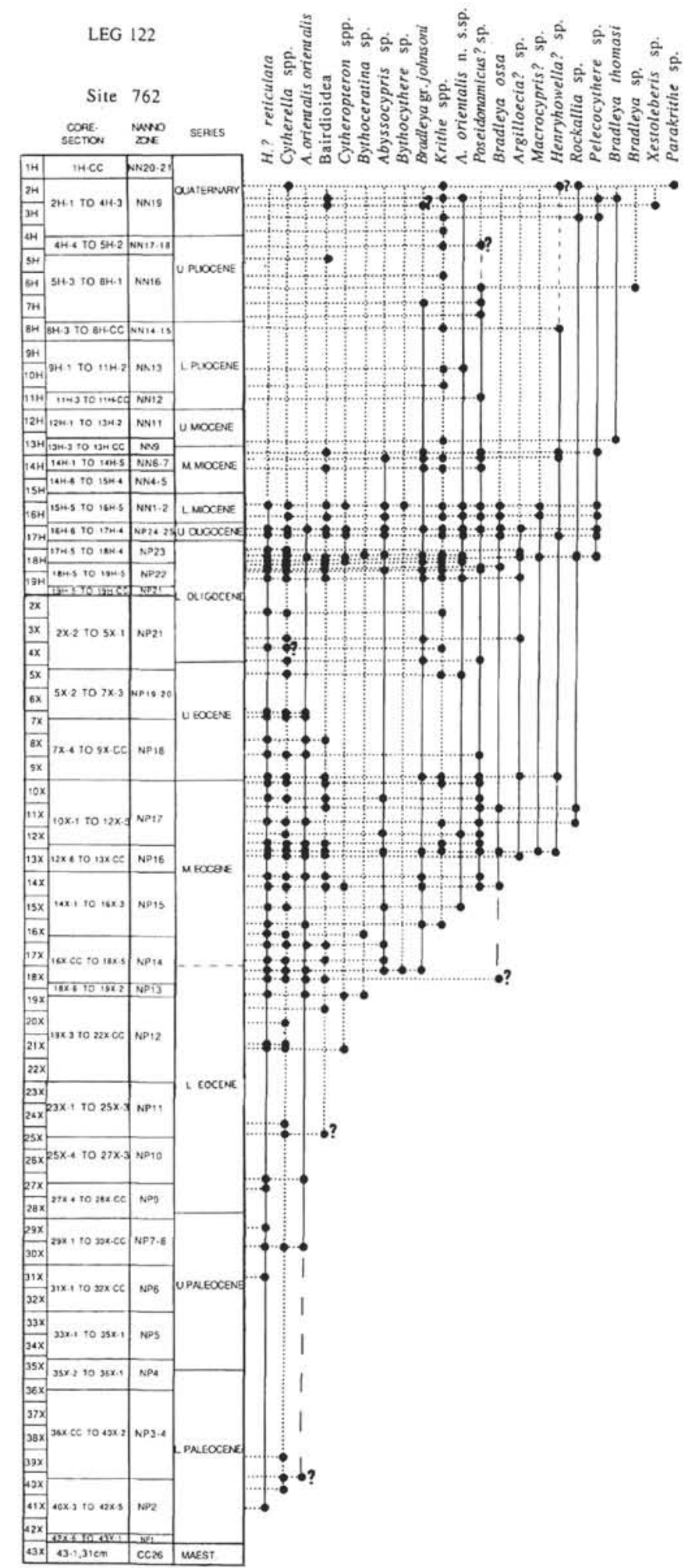


Table 2. Range chart for Cenozoic ostracodes from Site 763 (Holes 763A and 763B).

LEG

$$
\text { के 㝏 }
$$

\begin{tabular}{|c|c|c|c|}
\hline \multicolumn{4}{|c|}{ Hole $763 \mathrm{~A}$} \\
\hline ठั & $\begin{array}{c}\text { Foraminifer } \\
\text { zone }\end{array}$ & $\begin{array}{c}\text { Nanno- } \\
\text { fossil } \\
\text { zone }\end{array}$ & Series \\
\hline IH & N22-23 & NN2O-21 & \\
\hline
\end{tabular}

122 ป气

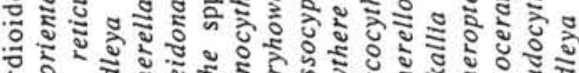

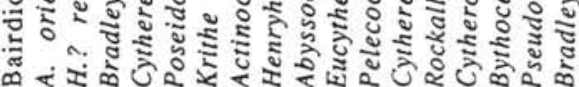

\begin{tabular}{|c|c|c|c|}
\hline రั & $\begin{array}{c}\text { Foraminlfer } \\
\text { zone }\end{array}$ & $\begin{array}{c}\text { Nanno- } \\
\text { fossil } \\
\text { zone }\end{array}$ & Series \\
\hline $2 x$ & P17 & \multirow{2}{*}{ NP2O } & \multirow{4}{*}{ upper Eccene } \\
\hline $3 x$ & P16-17 & & \\
\hline $4 \mathrm{x}$ & P15-16 & NP19 & \\
\hline $5 x$ & P14-15 & NP18 & \\
\hline $6 \mathrm{x}$ & $P_{12}$ & NP15.16 & \multirow{2}{*}{ middie Eocene } \\
\hline $7 x$ & P11 & NP15 & \\
\hline $8 x$ & upper Campanian & $\begin{array}{c}\text { upper } \\
\text { Campanian }\end{array}$ & $\begin{array}{c}\text { upper } \\
\text { Campanian }\end{array}$ \\
\hline
\end{tabular}
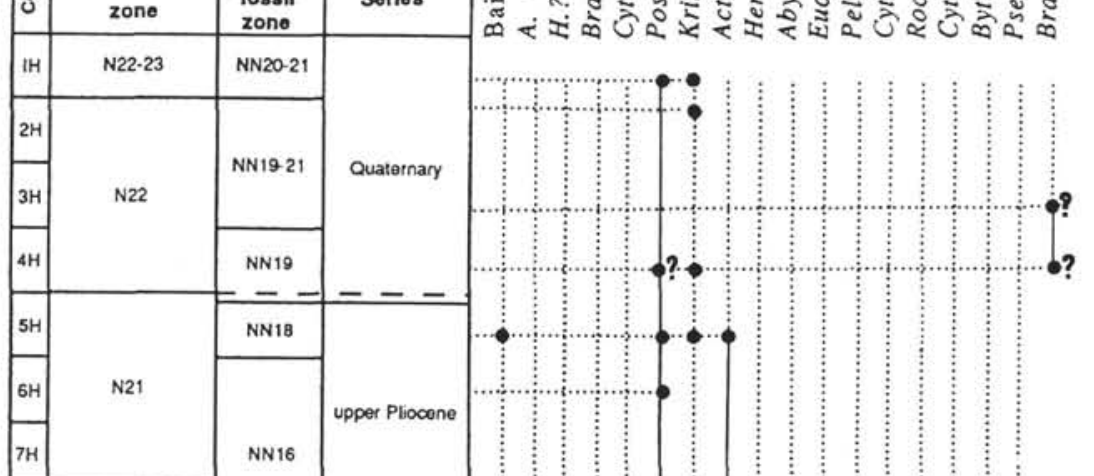

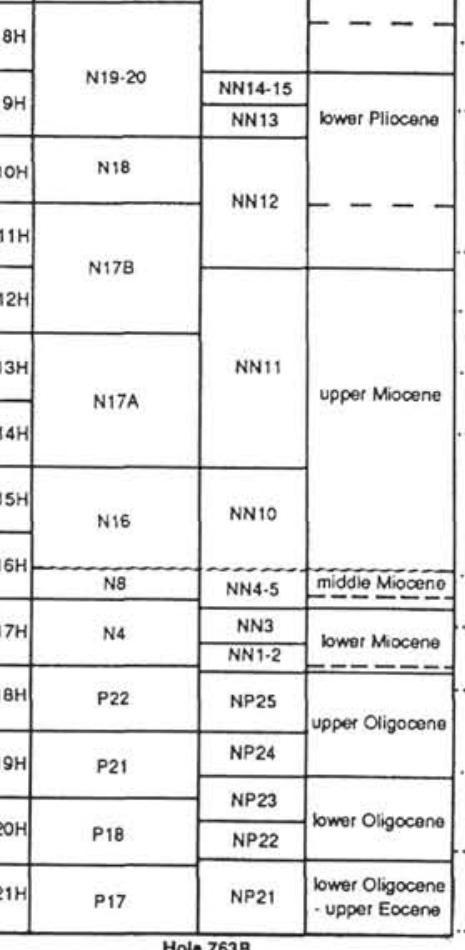
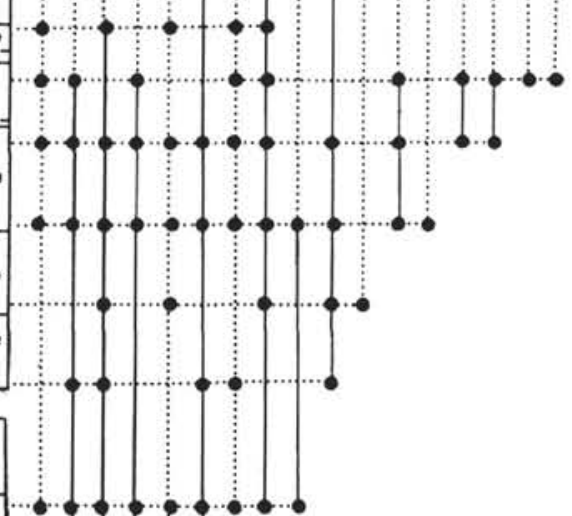


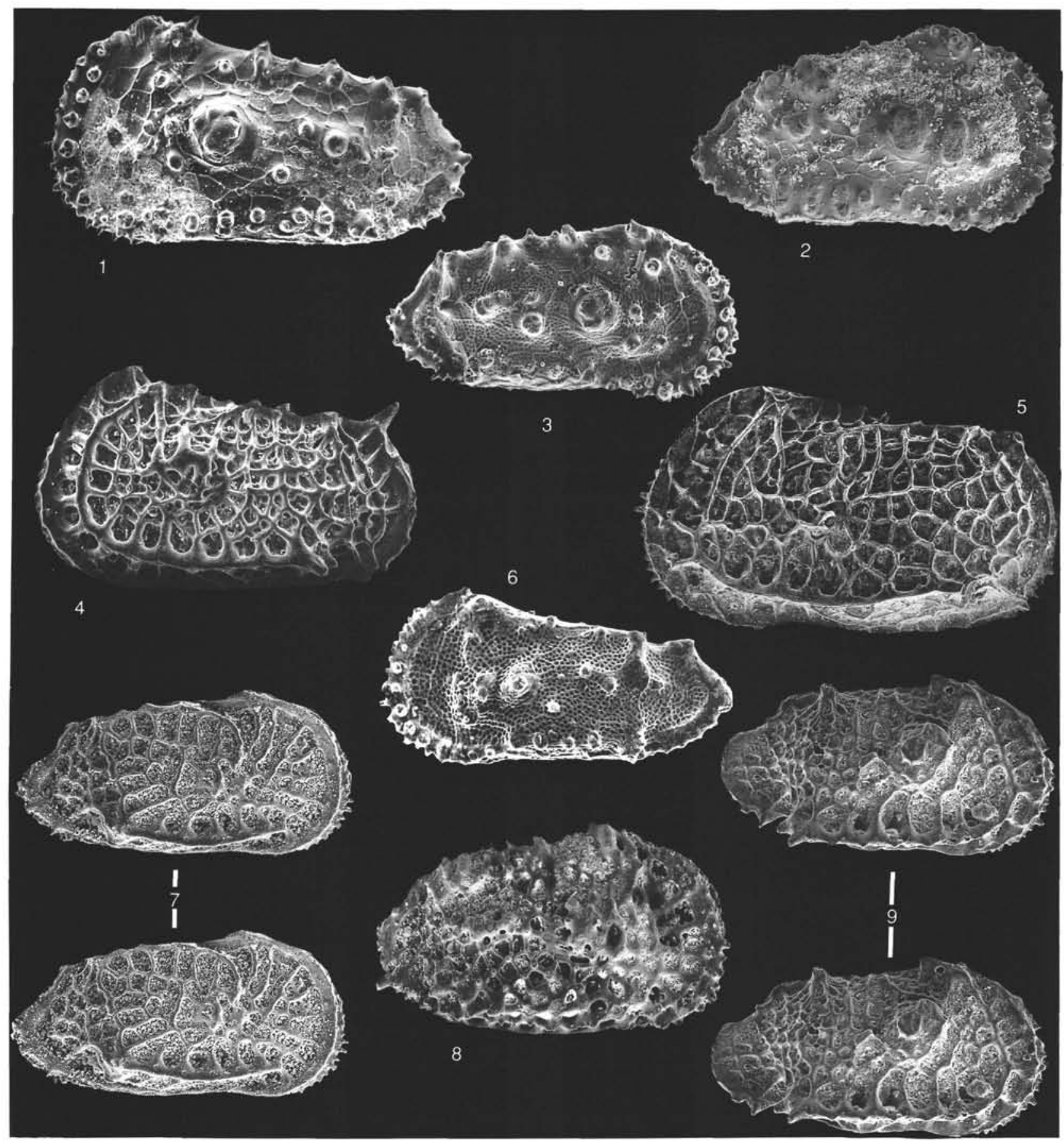

Plate 1. Cenozoic ostracodes of Leg 122. 1, 2. Actinocythereis orientalis orientalis; left valve, male (1), and right valve, female (2); $\times 62$; Samples 122-762B-18H-3, 10-12 cm (1) and 122-762C-30X-1, 132-134 cm (2). 3, 6. A. orientalis n.s. sp.; right valve (3) and left valve (6); $\times 60$; Samples 122-762B-16H-2, 74-76 cm (3), and 122-762B-18H-2, 10-12 cm (6). 4. Bradleya sp. gr. johnsoni; left valve, male; $\times 75$; Sample 122-762C-9X-CC. 5. Bradleya $\mathrm{cf}$. thomasi; left valve; $\times 60$; Sample 122-762B-2H-5, 67-69 cm. 7. Poseidonamicus sp. 1; right valve, male; $\times 60$; Sample $122-762 \mathrm{~B}-16 \mathrm{H}-2,76-78 \mathrm{~cm}$. 8. Henryhowella? reticulata; right valve; $\times 62$; Sample $122-762 \mathrm{C}-12 \mathrm{X}-5,88-89$ cm. 9. Bradleya ossa, right valve; $\times 60$; Sample $122-762 \mathrm{~B}-16 \mathrm{H}-2,74-76 \mathrm{~cm}$. 